\title{
Empowerment Strategies and Poverty Reduction in Bayelsa State: A Non-Parametric Approach
}

\author{
Peter Fiderikumo $^{1}$, Samson Bredino ${ }^{2}$, Adedoyin Adesuji ${ }^{3}$ \\ ${ }^{1}$ Department of Banking and Finance, Bayelsa State College of Arts and Science, Bayelsa State, Nigeria \\ ${ }^{2}$ Economics Department, University of Port Harcourt, Rivers State, Nigeria \\ ${ }^{3}$ Petroleum and Gas Engineering Department, University of Port-Harcourt, Rivers State, Nigeria \\ Email address: \\ Pfiderikumo@gmail.com (P. Fiderikumo)
}

\section{To cite this article:}

Peter Fiderikumo, Samson Bredino, Adedoyin Adesuji. Empowerment Strategies and Poverty Reduction in Bayelsa State: A Non-Parametric Approach. American Journal of Environmental and Resource Economics. Vol. 3, No. 1, 2018, pp. 1-5. doi: 10.11648/j.ajere.20180301.11

Received: December 22, 2017; Accepted: January 15, 2018; Published: March 21, 2018

\begin{abstract}
The incidence of poverty in Nigeria is rising despite a plethora of anti-poverty programmes and huge public expenditure. The objective of this study is to evaluate the extent and impact of three major empowerment strategies in the war against poverty namely social mobilization, skill development and capital formation in Bayelsa State. The study adopted a cross-sectional survey of Bayelsa State using structured and semi-structured questionnaire to collect primary data from 380 indigenous adult spread across 40 communities. The data was measured on the basis of the modified four points Likert scale and analysed using percentage and mean. The results depicted that social mobilization as a strategy is not used in reaching the poor. The implication is that to a great extent the impact of anti-poverty interventions do not get to the poor. The skill development programme although relevant and practical in approach has benefited only a limited number of people due mainly to hoarding of information, urban-biased, and nepotism. The participants are rarely supported with starter pack, tools, or finance. Procedure and requirement for obtaining business loan are tedious and fraught with nepotism. The empowerment programme has not resulted in capital formation and has not enhanced income of beneficiaries. It concluded that not sufficient resources are committed to these strategies. Therefore, increased use of the empowerment strategies will reduce poverty in Bayelsa State and Nigeria at large.
\end{abstract}

Keywords: Poverty, Empowerment, Social Mobilization, Skill Development, Capital Formation

\section{Introduction}

The worsening incidence of poverty necessitates continual assessment of anti-poverty strategies and programmes. The war on poverty in Nigeria is as old as the country itself. Successive governments at federal and state levels have spent huge sums of money on programmes and projects to alleviate poverty. [1] Indeed, since the inception of civilian rule the main thrust of government policy and budget has been on poverty reduction in line with the United Nation's Millennium Development Goals which has as central theme the eradication of extreme poverty in half by 2015 . Generally, the economic strategies of the intervention agencies have targeted at increasing the literacy rate; improving health delivery; improving access to credit facility for micro, small and medium scale enterprises; building capacity for employment opportunities; skill acquisition; low cost of housing; raising workers minimum wage; and infrastructural development. Poverty eradication strategies have also been aimed at removing social and legal barriers to income growth among the poor. Nevertheless, the country is still much characterized by mass poverty both at the urban and rural areas. Illiteracy is very high and capital formation is low. Consequently, productivity and income is extremely low.

Obadan identified a number of factors responsible for failure of anti-poverty interventions among which are lack of targeting mechanism, mismanagement/corruption, lack of participation of target group, policy inconsistency, poor coordination and implementation, politicization, inefficient integration of states and local governments, lack of mechanism for sustenance. [2] Empowerment is the main factor lacking in tackling poverty. [3] That is, investment in social and essential infrastructure that will enhance the 
capabilities of the poor. According to Odigwe, decisionmaking has been politicized with a lot of factors which make it non-participatory. [4 Similarly, Ibru argued that the poor performance of anti-poverty programmes results from strategies that are not adapted to the local conditions. [5] A bottom-up strategy that involves the poor in the formation and choice of poverty alleviation efforts is likely to be more successful than a top-down strategy in which bureaucrats presume to know what is best for the rural poor. In addition, according to Mankiw, studies conducted in the United States linked failure of antipoverty programme to the strategy which violates the first economic rule of urban poverty policy: programs should be person-based, not place-based. [6] Many anti-poverty programmes are targeted at poor areas and not the poor. The poor should be delineated and targeted for specific measures or policies that create transfers, entitlements or relief from regulation on the basis of personal characteristics.

Lessons drawn from the anti-poverty experiences of India, Bangladesh, Israel and Argentina lean support to empowerment as an effective measure in poverty reduction. [7] An empowerment approach to poverty reduction requires that the poor are given support to develop and fully utilize their productive capacities. Empowerment is anchored on a three-pronged strategy of social mobilization, skill development, and capital formation. Hence, the objective of the study is to evaluate the level and impact of empowerment through social mobilization, skill development and capital formation in Bayelsa State.

Research Questions

1. Is social mobilization used to galvanise active participation of the poor in poverty reduction programmes?

2. Is skill development of the poor significantly pursued as a strategy of poverty reduction?

3. Is capital formation of the poor significantly pursued as a strategy of poverty reduction?

\section{LITERATURE REVIEW}

Poverty: It has several definitions due to its complexity and multi-dimensional nature. [8] However, it is generally agreed that poverty connotes economic and non-economic deprivation or denial. [9] Poverty exists when people lack the means or income to satisfy basic human needs. [10] Experts identified three typologies of poverty namely: physiological deprivation, sociological deprivation, and human deprivation. [11]

There are many variants of poverty namely absolute, relative, and moderate, etc. The worse and biggest concern is absolute poverty also called extreme poverty or destitution. It is a situation in which the affected are unable to meet the minimum levels of income, food, clothing, health care, shelter, and other essentials in order to ensure continued survival. They are chronically hungry, unable to access health care, lack the amenities of safe water and sanitation, cannot afford education for some or all the children, lack rudimentary shelter and basic articles of clothing, such as shoes. [12]

Poverty can be examined at two levels: dimensions and causes. [13] In terms of dimensions, poverty can be seen as lack of access to tangible basic needs such as food, shelter, clothing, water, nutrition and health, education, as well as intangible ones like human dignity and freedom. And in terms of causes, poverty can be seen as an outcome of failure of endowments (land, savings, labour, membership in family/state/community), exchange entitlements (for produce, labour, state/family/community membership) and productivity of productive assets.

Empowerment: In the view of Rappaport, empowerment is the mechanism by which people, organizations, and communities gain mastery over their lives. Empowerment includes encouraging, and developing the skills for selfsufficiency, with a focus on eliminating the future needs for charity or social welfare in the individuals of the group. In economic development, the empowerment approach focuses on mobilizing the self-help efforts of the poor. [14] Empowerment is a process which relies on a three-pronged strategy of social mobilization of the poor, skill development and capital formation. [15]

Social Mobilisation: According to UNICEF social mobilization is "a broad scale movement to engage people's participation in achieving a specific development goal through self-reliance efforts. It involves relevant segment of society. It is a planned decentralized process that seeks to facilitate change for development through a range of players engaged in interrelated and complementary efforts. It takes into account the felt needs of the people, embraces the critical principle of community involvement, and seeks to empower individuals and groups for action." [16] Success and sustainability of a poverty alleviation programme depends entirely on the quality of social mobilization. [17] Social mobilization is the cornerstone of participatory approaches in rural development and poverty alleviation programmes. It is a powerful instrument in decentralization policies and programmes aimed at strengthening human and institutional resource development at local level.

Skill Development or Acquisition: It means the systematic process of imbibing new ideas and knowledge for executing accurately professional functions. Skill is the ability to do something well, gained through training or experience. [18] Skill development involves the development of new skill, practice or new way of doing things usually gained through training or experience. Human capital development takes the form of improved knowledge, better skills that workers acquire through education, training and experience. Human capital development requires adequate investment in strong educational system, on the job training, specialized training e.g. farm management, libraries, laboratories, teachers training. Human capital is the ultimate determinant of economic advancement. Rich countries are largely rich because of the skills of their populations and the quality of the institutions supporting economic activity. [19]

Capital Formation: According Hall \& Lieberman, capital is something produced that is long-lasting and used to produce other goods. [20] It also refers to the net addition of capital stock such as equipment, buildings and other intermediate 
goods. [21] A nation uses capital stock in combination with labour to provide services and produce goods; an increase in capital stock is known as capital formation. Capital enhances workers productivity. [22] Nigeria's small stock of physical capital stock (factories, machinery, farm equipment, and other productive capital) constrains labour productivity and holds back national output. [23] In all economies experiencing economic growth, capital expands at a more rapid rate than labour. That is the ratio of capital to labour $(\mathrm{K} / \mathrm{L})$ increases, and this too is a source of increasing productivity. [24]

\section{EMPIRICAL REVIEW}

Ikegwu et al studied the impact of human empowerment through skills acquisition in Nigeria using questionnaire method to collect primary data that were analysed using descriptive statistics, Chi square, and Friedman rank test. Results show that most respondents have learnt one skill or the other and would prefer to be empowered in areas like computer skill, hair dressing, tailoring and soap making, etc. It also demonstrated that skills acquisition have significantly contributed to society. The study concluded that skills acquisition contributes greatly in elimination of joblessness in Nigeria, development of positive attitude towards work, developing entrepreneurial ability, builds self-reliant young people, leads to technological advancement, reduce poverty and crime rate in the society.[25].

In a similar study by Idoko on skill acquisition and youth empowerment in Nigeria, it noted the importance of youth empowerment through skills acquisition programme for employment and enhanced self-reliance. The study recommended the establishment of skill acquisition centres in every nook and cranny of the country. [26]

\section{Method}

The study is a cross-sectional survey of the indigenous adult population of Bayelsa State, Nigeria. And the instrument employed was a combination of structured and semi-structured questionnaire, semi-structured interviews, field notes, and recordings of responses. The questionnaire was designed by the researchers and administered with the help of volunteers. Face validity method was used to ensure the instrument was valid for the study.

\subsection{Sample and Data Collection}

400 copies of questionnaire were administered to 40 communities which included all the local government headquarters and communities randomly selected on the basis of stratified sampling technique across Bayelsa State. The questionnaire was administered by the researchers and volunteers. Out of which, 380 representing 95 percent were retrieved but pruned to 148 representing 39 percent of respondents that had participated in any form of economic empowerment programme. Ultimately, our data analysis was based upon 148 responses. The respondents were men and women among whom were community leaders, youth leaders, heads of household, market or association leaders.

Table 1. Awareness and Participation in Economic Empowerment programmes.

\begin{tabular}{llll}
\hline Response & Yes (\%) & No (\%) & Total (\%) \\
\hline Programme awareness & $285(75)$ & $95(25)$ & $380(100)$ \\
Programme participation & $148(39)$ & $232(61)$ & $380(100)$ \\
\hline
\end{tabular}

Table 1 showed that awareness rate was 75 percent whereas programme participation rate fell to 39 percent of the total number of respondents.

\subsection{Method of Data Analysis}

The data was measured on the basis of the modified 4 points Likert scale namely strongly agreed $(\mathrm{SA})=4$, agree $(\mathrm{A})=3$, disagree $(\mathrm{D})=2$, strongly disagreed $(\mathrm{SD})=1$, and criterion mean $=2.5$. If the calculated mean is greater than or equals to the criterion mean we accept the proposition and when it is less we reject it. Data analysis was done using percentages and mean.

\section{Results}

The results of our data analysis in line with the research questions are presented as follows.

Results Regarding Question 1: Social mobilization and Poverty Reduction

Table 2. Social mobilization and Poverty Reduction.

\begin{tabular}{|c|c|c|c|c|c|c|}
\hline Item Statement & SA (4) & A (3) & D (2) & SD (1) & Mean & Decision \\
\hline The poor are mobilized as a strategy of poverty reduction. & 4 & 8 & 41 & 95 & 1.47 & Reject \\
\hline
\end{tabular}

Source: Author's computation from survey (2015).

Table 2 depicts the results from the responses to the Research Question 1 relating to the extent to which social mobilization is used as a strategy for poverty reduction. The calculated mean of 1.47 is less than the criterion mean of 2.5 .
Hence, we reject the proposition that the poor are significantly socially mobilized as a strategy of poverty reduction.

Results Regarding Question 2: Skill Development and Poverty Reduction

Table 3. Skill Development and Poverty Reduction.

\begin{tabular}{|c|c|c|c|c|c|c|}
\hline Item Statement & SA (4) & A (3) & D (2) & SD (1) & Mean & Decision \\
\hline Skill development is pursued as a strategy of poverty reduction. & 10 & 74 & 45 & 19 & 2.51 & Accept \\
\hline
\end{tabular}

Source: Author's computation from survey (2015). 
Table 3 shows the results from the responses to the Research Question 2 relating to the extent to which skill development is pursued as a strategy for poverty reduction. The calculated mean of 2.51 is greater than the criterion mean of 2.5 . Hence, we accept the proposition that skill development is significantly pursued as a strategy of poverty reduction.

Results Regarding Question 3: Capital Formation and Poverty Reduction

Table 4. Capital formation and Poverty Reduction.

\begin{tabular}{|c|c|c|c|c|c|c|}
\hline Item Statement & SA (4) & A (3) & D (2) & SD (1) & Mean & Decision \\
\hline Capital formation is pursued as a strategy of poverty reduction. & 10 & 39 & 62 & 37 & 2.02 & Reject \\
\hline
\end{tabular}

Source: Author's computation from survey (2015).

Table 4 shows the results from the responses to the Research Question 3 relating to the extent to which capital development is pursued as a strategy for poverty reduction. The calculated mean of 2.02 is less than the criterion mean of 2.5. Therefore, we reject the proposition that capital formation is significantly pursued as a strategy of poverty reduction.

\section{Discussion}

Social mobilization and Poverty Reduction (Question 1): The calculated mean of 1.47 indicates a high rejection of the proposition that the poor are mobilized as a strategy of poverty reduction. The implication of this shortcoming is that most residents are unaware and therefore cannot benefit from economic empowerment programmes. The worse effect is that the rural poor and the absolute poor do not have the opportunity to be reached. The practice of executing anti-poverty programmes without social mobilization of the poor defeats the essence of such programmes. It is also a violation of the first economic rule of the urban poverty policy which requires that anti-poverty programmes should be person-based and not placebased. Social mobilization is very vital in identifying the peculiar needs of the poor which will provide essential input in design of appropriate policy and workable programme. The problem with the geographic approach or place-base programmes is that their benefits go disproportionately to the strong or property owners in the target areas and not to the intended beneficiaries. Table 1 depicts that the participation in economic empowermrnt rate was low. Reasons given for this state of affairs included nepotism, inadequate sensitization or mobilization, programmes are mainly urban-centred, hoarding of information, cumbersome qualification procedure or requirement.

Skill Development and Poverty Reduction (Question 2): The calculated mean of 2.51 indicates a low acceptance of the proposition that skill development is significantly pursued as a strategy of poverty reduction. However, discussion with respondents reveals that skill acquisition programmes have resulted in limited success in empowering the poor. This is due mainly to the limited relevance of training programmes to the peculiarity of the communities. In addition, most of the poor do not have the opportunity to partake in skill acquisition programme due to information hoarding, the programmes are mainly urban-centred, nepotism, and lack of social mobilization. Capacity building should not be generalized but aimed at improving productivity particularly in traditional vocations such as improved farming and fishing methods. This view is supported by studies which attached importance for the need to develop indigenous productive capacity or appropriate technology. It also underscores the need for effective social mobilization of the poor before the execution of training programmes.

Capital Formation and Poverty Reduction (Question 3): The calculated mean of 2.02 indicates a low rejection of the proposition that capital formation is significantly pursued as a strategy of poverty reduction. Participants are hardly supported with starter pack, tools or finance. More often than not participants have been given inferior or refurbished tools. Instances were cited in which refurbished or inferior tools were distributed instead of new ones. Access to credit facilities or financial assistance promised was hardly kept. The procedure and requirement for obtaining credit facility is tedious or is fraught with nepotism. Thus, empowerment programme has not resulted in either enhanced capital formation in the communities or improved income of beneficiaries.

\section{Conclusion}

The study has evaluated the extent and impact to which social mobilization, skill development, and capital formation strategies are pursued in poverty reduction in Bayelsa State, Nigeria.

We conclude that not sufficient resources are committed to these strategies. Therefore, these economic empowerment strategies should be enhanced to significantly reduce poverty in Bayelsa State.

Although, the study centred on Bayelsa State, it is believed that the findings may not be different from other states in Nigeria.

\section{References}

[1] Tamuno, S. O. (2013). A Collection of Selected Works on Development Issues in Nigeria. Port Harcourt: Havey Publications Coy.

[2] Obadan, M. I. (2003). Poverty Reduction in Nigeria: The Way Forward. CBN Economic Review, Vol. 39, No. 4.

[3] Odigwe, W. D. (2002). Poverty Alleviation: The Nigerian Experience and the Way Forward. Management in Nigeria, Journal of NIM, Vol. 38 No. 3: pp 14-22. 
[4] Ibru C. A. O. Poverty Alleviation From The Grassroots: Modalities, Prospects And Problems A paper presented at the $6^{\text {th }}$ Bankers' Conference Organised by the Chartered Institute of Bankers of Nigeria. September 2000.

[5] Mankiw, N. G. (2009). Principles of Economics. Mason: South-Western Cengage Learning.

[6] Mankiw, N. G. (2009). Principles of Economics. Mason: South-Western Cengage Learning.

[7] Murthy R. B, Raju K. \& Kamath A. (2003). Towards Women Empowerment and Poverty Reduction: Lessons from the participatory Impact Assessment of South Asian Poverty Alleviation Programme in Andhra Pradesh, India.

[8] Oladeji, S. I. (2012). Lecturer Note on Definition of Measurement of Poverty. Department of Economics, Obafemi Awolawo University Ile-ife.

[9] Todaro, M. P. (1982). Economics for a Developing World. Longman Group Limited, Essex, UK.

[10] Nwosu, E. J. (2002). The Challenge of Poverty in Africa. Owerri: Skillmark Media Ltd.

[11] Tamuno, S. O. (2013). A Collection of Selected Works on Development Issues in Nigeria. Port Harcourt: Havey Publications Coy.

[12] Sachs, J. D. (2005). The End of Poverty. London: Penguin Books.

[13] Murthy R. B, Raju K. \& Kamath A. (2003). Towards Women Empowerment and Poverty Reduction: Lessons from the participatory Impact Assessment of South Asian Poverty Alleviation Programme in Andhra Pradesh, India.

[14] Rappaport, J. (1981). In Praise of Paradox. A Social Policy of Empowerment over Prevention. American Journal of Community Psychology, Vol. 9 (1), 1-25 (13).
[15] Murthy R. B, Raju K. \& Kamath A. (2003). Towards Women Empowerment and Poverty Reduction: Lessons from the participatory Impact Assessment of South Asian Poverty Alleviation Programme in Andhra Pradesh, India.

[16] www.unicef.org.

[17] Sindh Rural Support Organisation (SRSO) www.srso.org.pk.

[18] Business: The Ultimate Resource (2006). Basic Books, A \& C Black Publishers Ltd.

[19] Mankiw, N. G. (2009). Principles of Economics. Mason: South-Western Cengage Learning.

[20] Hall, R. E \& Lieberman (2005). Microeconomics: Principles and Applications. Thomson: South- Western.

[21] Wonnacott, P. \& Wonnacott, R. (1983). Economics. Mc GrawHill, Inc. Auckland.

[22] Naanen, B. B. (2015), The Prosperity and Poverty of Nations: Using Global Models to Explain and Mitigate Underdevelopment in Nigeria. University of Port Harcourt. Inaugural Lecture Series. No. 119.

[23] Mankiw, N. G. (2009). Principles of Economics. Mason: South-Western Cengage Learning.

[24] Ikegwu E. M, Ajiboye Y. O, Aromolaran A. D, Ayodeji A. A. \& Okorafor U. (2014). Human.

[25] Empowerment Through Skill Acquisition: Issues, Impacts and Consequences-A Non-Parametric View. Journal of Poverty, Investment and Development- An Open Access International Journal. Vol. 52014.

[26] Idoko, C. U. (2014). Skill Acquisition and Youth Empowerment in Nigeria. Global Journal of Commerce and Management Perspective (www.gifre.org), Vol. 3 (1): 51-54. 